\title{
SLIKA SUVREMENOG ODGOJITELJA U PARADIGMI RANOG I PREDŠKOLSKOG ODGOJA I OBRAZOVANJA
}

\author{
Željka Pintar \\ Dječji vrtić Kustošija, \\ Zagreb, Hrvatska \\ zeljka.pint@gmail.com
}

Primljeno: 1. 4. 2020.

\begin{abstract}
U radu se tematizira preobrazba tradicionalnog odgojitelja biheviorističke odgojno-obrazovne paradigme, svojstvene socijalističkom razdoblju u Republici Hrvatskoj, u suvremenog odgojitelja, zagovornika konstruktivističkog odgojno-obrazovnog koncepta, svojstvenog razdoblju demokratskog života $u$ istom kontekstu. U radu se nastoji uputiti na ključne razlike između tradicionalnog i suvremenog odgojitelja, a ujedno i na njihove srodnosti, kako bi se bolje razumjela očekivanja i kriteriji za procjenu uspješnosti djelovanja u aktualnoj odgojno-obrazovnoj djelatnosti. Tematizira se implicitna pedagogija kao odgojiteljeva subjektivna odgojno-obrazovna teorija te se ukazuje na opravdanost shvaćanja implicitne pedagogije kao ključnog konstrukta odgojno-obrazovnog koncepta. Također se upućuje i na važnost refleksivne prakse kao sastavnice odgojiteljeva profesionalnoga razvoja te se problematizira provedba akcijskih istraživanja kao instrumenta razvoja odgojiteljeve djelatnosti.
\end{abstract}

Ključne riječi: suvremeni odgojitelj, implicitna pedagogija, akcijsko istraživanje

\section{Uvod}

Suvremena pedagogija izložena je brojnim izazovima. Ponajprije, prisutan je problem definiranja osnovnih predmeta izučavanja pedagogije. Ona istražuje intencionalne i funkcionalne fenomene odgoja, obrazovanja i izobrazbe mladog naraštaja i odraslih osoba (Mijatović, 2000), 
a određivanje navedenih pojmova je raznoliko. Prema nekim definicijama odgoj je određen kao proces organiziranog (namjernog) razvijanja voljnih osobina čovjeka, dok se obrazovanje određuje kao organizirano i sustavno razvijanje kognitivnih sposobnosti i učenja pojedinaca (Mijatović, 2000). Pristup odgoju u hrvatskoj pedagoškoj literaturi kontinuirano je razrađivan kroz tri osobito značajna i različita koncepta (Vukasović, Pastuović, Polić M.), vezana uz poimanje bîti čovjeka (Bognar, 2015). Vukasović tako tumači odgoj kao vrijednosno utemeljeno prenošenje prethodnih iskustava čovječanstva novim naraštajima, a koji se djelatno i stvaralački odnose prema svijetu (Vukasović, 1989, prema Bognar, 2015). Drugi autori, poput Pastuovića, odgoj određuju kao organizirano afektivno učenje (Pastuović, 1999, prema Bognar, 2015), no to se tumačenje smatra nedostatnim zbog nedovoljnog distanciranja čovjeka od srodnih vrsta (Bognar, 2015). Kombinirajući dva prethodna pristupa, Milan Polić razumije odgoj kao ukupnost postupaka kojima se, u okviru određene kulture, slobodonosno razvijaju čovjekove moći (Polić M., 2010, prema Bognar, 2015). Prema suvremenom pedagoškom modelu u razmatranju pojmova odgoja i obrazovanja ne problematizira se samo treba li ih eventualno redefinirati nego i treba li ih napustiti (Milat, 2007). Tako se u kontekstu suvremene paradigme ranog i predškolskog odgoja i obrazovanja sve više, umjesto o odgoju i obrazovanju, govori o socijalizaciji i učenju (Gudjons, 1994, prema Milat, 2007). Suvremeno shvaćanje čovjeka kao subjekta vlastitoga razvoja rezultira pojavom »samoaktivnog subjekta« i konceptom »samosocijalizacije« (Luhman, 1986, prema Bašić, 2009) čime se relativizira ili potpuno ukida odgojna odgovornost odraslih spram djece (Bašić, 2009).

Pojedini autori navode važnost odgoja za vrijednosti, koji nije samo intelektualne nego i čuvstvene ili emocionalne prirode (Mougniotte, 1995, prema Miliša et al., 2015). Pritom se naglašava da je cilj odgoja za vrijednosti postići ne samo spoznaju nego i potaknuti volju, jer sama spoznaja nije dovoljna za nečiji angažman (Miliša et al., 2015). Također se pokreću programi tzv. filozofije za djecu koji podrazumijevaju poticanje djece na rasprave $u$ kojima ona iznose vlastita uvjerenja $\mathrm{i}$ vrijednosti te razmatraju stavove drugih (Ćurko i Kragić, 2008). Pritom je uloga učitelja organizacija i uspostavljanje općih uvjeta rasprave, dok djeca određuju njen tijek (Šimenc, 2008) što odgovara neizravnom, deskriptivnom pristupu poučavanja vrijednosti (Rakić i Vukušić, 
2010). Napominje se kako je odgoj za vrijednosti povezan s moralnom krizom društva u kojemu nestaju tradicionalne vrijednosti, a istodobno se ne stvaraju nove, što se povezuje sa sve većim antisocijalnim ponašanjima među mladima (Etzioni, 2002, prema Rakić i Vukušić, 2010). Ono što je zamjetno jest izdvajanje pojma 'vrijednost' iz pojma 'odgoj' u sintagmi 'odgoj za vrijednosti' čime se sugerira njihova moguća razdvojenost. Ako uvažimo da su vrijednosti pokretački i regulacijski čimbenik odgoja (Mougniotte, 1995, prema Miliša et al., 2015), onda iskaz 'odgoj za vrijednosti' zapravo postaje tautološki. Iako se navodi da zbilju suvremenog svijeta obilježava kriza vrijednosti, kriza morala, obesmišljenje i razaranje života (Novalić, 2003), određivanje odgoja za vrijednosti upućuje i na krizu shvaćanja samoga odgoja.

Milan Polić (2015) naglašava da je način određivanja sadržaja pojma 'odgoj' presudan za sudjelovanje odgojitelja u pedagoškom procesu. Pojašnjava kako odgoj treba biti zasnovan razložno, što podrazumijeva da se njime možemo uspješno baviti jedino ako promišljamo sam pojam odgoja, ne uzimamo ga površno, u pogrešnom ili približnom shvaćanju. U tome smislu, između ostalog, Polić ističe distinkciju pojmova 'odgoj' i 'manipulacija': dok se manipulacijom smatraju postupci prikrivenog upravljanja ljudima kao sredstvima radi postizanja neke njima izvanjske svrhe, odgoj podrazumijeva usmjerenost pojedincu, razvitku njegove osobnosti i njegovanju njegove slobode kao mogućnosti samoodređenja po kojoj on tek jest osoba (Polić M., 2015).

Nepostojanje jednoznačno definiranih osnovnih pedagoških pojmova otežava preciziranje problema pedagoških istraživanja i znanstveno-metodološko određivanje (Milat, 2007). Sekulić-Majurec (2007) navodi da nedostatna razrada metodologije pedagoških istraživanja predstavlja istaknut izazov suvremenom pedagoškom konceptu. Mužić (1999) ističe da se metodologija istraživanja odgoja i obrazovanja pojavljuje u dvije osnovne znanstvene paradigme: paradigmi razumijevanja i paradigmi pojašnjavanja (Mužić, 1999). Primjena istraživanja obiju paradigmi potencijalno proizlazi iz povezanosti pedagogije sa srodnim znanostima. Suvremena pedagoška paradigma dominantno se zasniva na konstuktivizmu, psihološkoj teoriji učenja. Psihologija razrađuje metodologiju istraživanja svojstvenu svom predmetu. Međutim, da bi se razumjela svrha odgoja, važno je razumjeti i filozofska polazišta pedagoških paradigmi. Pojedini autori razrađuju upravo spe- 
cifičnost filozofske metode u odnosu na druge znanosti (Mužić, 2007). Također se i sociološki promatraju opće društveno-političke prilike koje utječu na domenu odgoja i obrazovanja. Suvremenu pedagogiju obilježava znatna društvena uvjetovanost institucionalnih odgojno-obrazovnih ciljeva. Tako se u obrazlaganju polazišta suvremene pedagoške paradigme često spominju obilježja suvremenog doba koje zahtijeva specifičan modalitet odgojno-obrazovnog djelovanja. Obrazovanje se smatra sastavnim dijelom nacionalnih programa za prilagođavanje zahtjevima globalizacije i prijelaz na ekonomiju utemeljenu na društvu znanja (Baranović, 2006). Primjerice, Strategijom znanosti, obrazovanja i tehnologije (2014) ističe se važnost promišljanja o mjestu koje u društvu zauzimaju znanost i obrazovanje, a s ciljem stvaranja inovativnog društva i gospodarstva u kojima je znanje na prvome mjestu u projekcijama strateškoga razvoja. U Deklaraciji o znanju (2004) navodi se da se obrazovanjem teži potaknuti razvoj društva znanja jer se obrazovanje smatra temeljnom proizvodnom snagom i uvjetom gospodarske uspješnosti. Naglašava se važnost odgoja i obrazovanja pojedinaca kao građanina Europe, spremnih doprinijeti razvoju globalno konkurentnog društva, a također se tematizira i poticanje razvoja ljudskog kapitala putem obrazovanja (Keeley, 2009). Dominantna predodžba o pedagogiji danas jest da je ona primijenjena znanost kojoj tzv. temeljne znanosti, poput filozofije, sociologije ili psihologije, pripremaju teorijske spoznaje i upotrebljiva znanja (Palekčić, 2010). Ako se pedagogija želi afirmirati kao autonomna znanost (Komar, 2008), onda je potrebno da se okrene svrsi odgoja koja ne proizlazi iz ciljeva koje postavlja država, neka konfesija ili ekonomija (Palekčić, 2010). Komar (2008) navodi da se autonomno određena pedagogija usustavlja na svom temeljnom pojmu - obrazovljivosti. No, kako je prethodno navedeno, suvremena pedagoška paradigma usredotočuje se na školu promatranu iz društveno-političke pozicije, uz zanemarivanje svrhe škole kako je određuju pedagoško-teorijske pozicije (Palekčić, 2002). Suvremenoj pedagoškoj paradigmi nedostaju teorijske osnove i empirijski izrađeni pojmovi. Primjerice, nije jasno na koji bi način kompetencije, na čijem se određenju bazira suvremeni pedagoški koncept, trebale zamijeniti osnovne pedagoške termine poput obrazovanja (Palekčić, 2014). Stoga, kako navodi Komar (2008), suvremeni pedagoški koncept ne usustavlja svoj predmet te nije svjestan svoje empirijske manifestacije. 
Uz razumijevanje znanstveno-stručnih polazišta na kojima se temelji odgojno-obrazovna praksa te društvenih očekivanja koja se vežu uz odgoj i obrazovanje, u suvremenom se pedagoškom konceptu ističe i značaj razmatranja odgojiteljeve osobne koncepcije odgoja, njegove implicitne pedagogije. Smatra se (Petrović-Sočo, 2009) kako odgojiteljeva osobna pedagoška teorija može odmicati od službenog, društveno proklamiranog odgojno-obrazovnog ideala te time odgojiteljevo subjektiviziranje odgojno-obrazovne prakse postaje moguć distraktor njezina razvoja. Upravo je zato u ovome radu implicitna pedagogija $u$ središtu interesa.

U kontekstu terminologije vezane uz pedagoški stručni kadar, zamjećuje se kako su u određenim europskim dokumentima (Common European Principles for Teacher Compentences and Qualifications, 2005) terminom 'učitelj' obuhvaćeni odgojno-obrazovni djelatnici svih razina obrazovanja, od predškolskog, osnovnoškolskog i srednjoškolskog, sve do viših i visokih škola i veleučilišta. Budući da nacionalni kurikulumi svih razina obrazovanja ističu jednake osnovne principe pristupa odgoju i obrazovanju, u kontekstu ovoga rada izmjenjivat će se termini, ali i razmatranja tematski vezana uz odgojitelje i učitelje, premda je primaran interes upućen upravo odgojiteljima djece rane $\mathrm{i}$ predškolske dobi.

Uzimajući u obzir znanstvene značajke i društvenu uvjetovanost pedagoške znanosti, kao i izazove s kojima se suvremeni pedagoški koncept suočava, u ovome će se radu razmatrati stručni profil, institucionalna slika i status odgojitelja u odgojno-obrazovnom sustavu. Nastojat će se promotriti postojeća institucionalna pozicija odgojitelja kao neposrednih nositelja odgojno-obrazovnog procesa u ustanovama ranog i predškolskog odgoja i obrazovanja, s ciljem razmatranja pretpostavki koje im mogu omogućiti emancipiranje u vidu odgojno-obrazovnih profesionalaca.

\section{Tradicionalni i suvremeni odgojitelj - srodnosti i razlike}

Suvremena obrazovna paradigma se, u svim svojim segmentima pa tako i onome koji definira karakteristike poželjnoga odgojitelja, predstavlja kao opozicija tradicionalnom pedagoškom konceptu. Suvremeni 
pedagoški koncept kao jednu od karakteristika tradicionalnog odgojitelja navodi njegovo podčinjavanje i obespravljivanje djece (Slunjski, 2011), dok suvremeni odgajatelj omogućuje potpunu afirmaciju djetetove osobnosti. Afirmacija djetetove osobnosti podrazumijeva autonomno samoodređenje djeteta. Gojkov (2009) naglašava da nastava ne treba rezultirati samoodređenjem, već da ga treba odmah omogućiti. Samoodređenje se tako ne poima kao cilj pedagoškog procesa, nego kao jedini važeći organizacijski kriterij (Gojkov, 2009). Odgojitelj i dijete uspostavljaju simetričan, partnerski odnos u kojemu zastupnička uloga odraslih spram djece, u smislu pedagoške odgovornosti, gubi na značaju (Bašić, 2009). Oslobađanje od ovisnosti o odraslima i samoodređenje zadobivaju karakter zahtjeva za autonomijom koja se djetetu nalaže i u odnosu na koju se treba dokazivati (Bašić, 2009). Suvremeni pedagoški koncept objašnjava da je odgoj za zrelost suprotan svemu što teži tome da se ljudi drže na uzici, da ih se podčini onome što se smatra dobrim i unaprijed sačuva od onoga što se smatra lošim; odgoj za zrelost je odgoj za uspjeh i prosudbu, samodisciplinu i samokritiku (Hentig, 2006, prema Slunjski, 2012). Pritom se zanemaruje činjenica da je djetinjstvo specifično razdoblje djetetove psihičke i tjelesne nezrelosti te da je zbog toga dijete, uz priznavanje svih njegovih prava, potrebno i zaštititi (Konvencija o pravima djeteta, 2001). Također se previđa da je djetinjstvo zapravo ustanovljeno pretpostavljenom granicom spram odrasle dobi. Ta granica štiti djetinjstvo kao doba razvoja, doba koje je oslobođeno odgovornosti za osobni razvoj i socijalne odnose (Jull i Helle, 2005, prema Bašić, 2012). Dok pojedini autori naglašavaju važnost poznavanja djetetova razvoja kako bismo bili u mogućnosti kompetentno mu doprinositi (Starc et al., 2004), drugi se suprotstavljaju takvom psihološkom pristupu djetetovim potrebama te zagovaraju sociološki pristup njegovim pravima (Prout i James, 1997, prema Polić, P., 2015). Autori (Polić, P., 2015) naglašavaju važnost razrade pedagogijskog pristupa problemu odnosa potreba i prava djece te nužnost definiranja potreba i prava djeteta iz pedagogijske perspektive.

Težeći distanciranju od tradicionalnog pedagoškog koncepta i njemu svojstvenog odgojitelja, suvremeni pristup često potencira pitanja koja zagovaraju opredjeljivanje odgojitelja, poput »Želim li da dijete ima čvrst vanjski autoritet (pravilo, zahtjev, zabranu) ili čvrst unutarnji autoritet (samostalno i odgovorno biranje onoga što će reći, učiniti, 
odlučiti)?« ili »Želim li razvijati poslušnost ili inicijativnost djece?« (Slunjski, 2011, 45). Pritom su priklanjanje vanjskom autoritetu i poslušnost pokazatelji naklonosti prema prevladanom obrascu odgoja. I u sferi metodičkih postupaka suvremeni koncept ranog i predškolskog odgoja i obrazovanja zagovara striktan odgojiteljev odabir. Tako se retorički polemizira treba li odgojitelj djecu izravno pozvati u aktivnost ili je dovoljno samo ponuditi odgovarajuće materijale koji djecu neizravno pozivaju na uključivanje (Slunjski, 2011). Suvremena pedagoška paradigma tendira postavljanju pitanja u vidu sukobljenih alternativa, oprečnih opcija i proturječnih zahtjeva, iako se navedeni odabiri mogu promatrati i kao komplementarne i nadopunjujuće mogućnosti. Tako je važno da dijete bude inicijativno, ali i spremno za kompromis, sposobno prihvatiti autoritativan autoritet, i u tome smislu poslušno. Značajno je da djeca borave u bogatom prostorno-materijalnom kontekstu, no navedeno ne implicira nedozvoljivost odgojiteljeva iniciranja zajedničke aktivnosti s djecom. Petrović-Sočo (1997) navodi da su vođene aktivnosti u tradicionalnom odgojno-obrazovnom modelu rada započinjale odgojiteljevim davanjem naloga djetetu da ono počne nešto činiti. Nadalje, inzistira se (Petrović-Sočo, 1997) na negativnom vrednovanju vođenih aktivnosti, premda sama ideja odgojitelja da okupi djecu u vođenoj formi odgojno-obrazovnog rada ne mora nužno podrazumijevati odgojiteljevu direktivnu, intruzivnu, suvišno dominantnu i podčinjavajuću namjeru da linearno, mehanički, kontrolirano i unificirano upravlja procesom učenja djece u pojedinoj aktivnosti. Bašić (2015) upućuje da aktivirajuća i voditeljska uloga učitelja ne podrazumijeva nužno direktivnu komunikaciju. Autori također napominju kako izravno podučavanje nije u suprotnosti sa shvaćanjem o aktivnom konstruiranju znanja (Babić i Irović, 2001, prema Palekčić, 2002). Govoreći o predavačkoj nastavi zaključuje se (Palekčić; 2002) da ona ne implicira nužno pasivno učenje, nego da je u okviru tako strukturirane nastave itekako moguća učenikova intelektualna aktivnost. Naglašava se kako se prijenos znanja i stjecanje znanja ne mogu oštro odvajati (Palekčić, 2002). Učiteljeva uloga facilitatora i aktivatora samo su naizgled u proturječju. Dok strategije učiteljeva aktiviranja učenika obuhvaćaju direktne upute, razne oblike prezentiranja, pokazivanja i poučavanja, među strategijama učitelja moderatora samoregulirajućeg učenja nalaze se individualizirana instrukcija, problemsko učenje, induktivno učenje (Bašić, 
2015). Pritom treba napomenuti da neki empirijski nalazi daju prednost nastavi u kojoj je učitelj pokretač i voditelj procesa učenja jer je takvo ponašanje učitelja procijenjeno više pozitivnim u odnosu na facilitativne oblike (Hattie, 2009, prema Bašić, 2015).

Razmatrajući proces stjecanja znanja, suvremena paradigma ranog i predškolskog odgoja i obrazovanja tumači kako suvremeni odgojitelj dijete smatra aktivnim sudionikom vlastitoga učenja, dok je ono, po shvaćanju tradicionalnog odgojitelja, bilo smatrano objektom poučavanja (Petrović-Sočo, 2009a). Prema Miljak (1996), tradicionalni pedagoški koncept obilježen je transmisijskim pristupom usvajanju znanja metodom izravnog poučavanja, dok je suvremeni koncept karakteriziran transakcijsko-transformacijskim pristupom koji podrazumijeva interaktivno konstruiranje i rekonstruiranje vlastitog znanja (Miljak, 1996). Prema Bloomovoj taksonomiji znanja (Nimac, 2011), najniža razina znanja je ona koja obuhvaća dosjećanje i definiranje pojmova, što zapravo predstavlja razinu transmisijski prenosivog činjeničnog znanja. Bloomovom se taksonomijom potom navodi znanje na razinama shvaćanja, primjenjivanja, analiziranja, evaluiranja i sintetiziranja, a dosezanje tih razina znanja transakcijsko-transformacijski pristup definira kao svoj cilj (Miljak, 1996). Transmisijom znanja moguće je upoznati učenike s činjeničnim sadržajem koje je preduvjet za stjecanje znanja na narednim razinama. Nemoguće je doseći razinu svjesne primjene naučenog ako ne raspolažemo elementarnim poznavanjem temeljnih pojmova i definicija. Transmisijom znanja naglašava se učiteljeva aktivnost, djelatnost prenošenja činjeničnih znanja, a ona je upravo i jedino moguća na elementarnoj razini znanja. Usvajanje znanja viših razina učitelj nužno treba poticati, ali ne može njima, kako se navodi u Nacionalnom kurikulumu za rani i predškolski odgoj i obrazovanje (2014), upravljati. Razumijevanje, primjenjivanje, vrednovanje, analiziranje i sintetiziranje zahtijevaju korištenje sposobnosti mišljenja višega reda te se tiču djetetove mentalne obrade informacija. Iako se tvrdi da je tradicionalni odgojitelj osmišljavao sadržaje koje je posredovao djetetu, navedeno ne podrazumijeva da je to bila jedina razina znanja za koju je odgojitelj smatrao da odgojno-obrazovnim procesom treba biti dosegnuta. Unatoč tome što transformacijski pristup učenju u konceptu suvremene paradigme naglašava više razine Bloomove taksonomije, odnosno sposobnosti kombiniranja činjenica i ideja, rekonstrukcije i 
reorganiziranja informacijskih cjelina, poopćavanja, objašnjavanja, pretpostavljanja, zaključivanja i interpretiranja (Nimac, 2011), one su zapravo nadgradnja elementarne razine poznavanja faktografskog znanja. U tom je smislu, umjesto isključivosti odabira transakcijskog ili transmisijskog pristupa usvajanju znanja, važno odgojiteljevo osmišljavanje njihove komplementarne primjene.

Suvremeni odgojitelj, promovirajući koncept aktivnog učenja, zalaže se za primjenu projektne nastave, učenja otkrivanjem, grupnog rada u kojemu se potiče djetetova samostalna aktivnost. Autori navode da djeca sama znaju koja su znanja vrijedna učenja (Slunjski, 2011c). U Nacionalnom okvirnom kurikulumu (2011, prema Slunjski, 2011a) naglašava se da u procesu djetetova učenja valja uvažavati njegovu sposobnost samopoticanja na djelovanje, samoorganiziranja i samovođenja aktivnosti, samostalnost u obavljanju aktivnosti, kao i samostalnost djelovanja, mišljenja i odlučivanja (Nacionalni okvirni kurikulum za predškolski odgoj i obrazovanje te opće obvezatno i srednjoškolsko obrazovanje, 2011, prema Slunjski, 2011a). Individua svoju stvarnost autonomno konstruira, bez nastavnikova izravnog posredovanja znanja (Palekčić, 2002). Indirektno sudjelovanje nastavnika u procesu učenja podrazumijeva da je njegov zadatak pripremiti okolinu za učenje, u kojoj će učenici samostalno raditi i učiti. Suvremeni pedagoški koncept upućuje odgojitelja na zadaću stvaranja uvjeta za samostalno učenje putem materijalnog okruženja (Slunjski, 2011a). Suvremeni odgojitelji prilikom pripreme materijala za aktivnosti djece trebaju razmotriti jesu li materijali dovoljno raznoliki i osmišljeni na način da ih mogu koristiti djeca raznih kompetencija, odgovaraju li interesima i individualnim mogućnostima djece, potiču li na samostalno korištenje i suradnju, mogu li djeca njihovim korištenjem naučiti nešto novo te jesu li usklađeni s postojećim znanjem i iskustvom djece (Slunjski, 2011b). Materijali djecu trebaju poticati na postavljanje, provjeravanje, revidiranje vlastitih pretpostavki i osobnih zamisli o određenom problemu te im olakšavati komuniciranje o idejama i novim spoznajama s drugom djecom (Sindik, 2008). Objašnjavajući vlastite stručne zadaće, suvremeni se pedagoški koncept osvrće i na zadaće tradicionalnih odgojitelja. Ističe se kako su stručne zadaće tradicionalnih odgojitelja bile shvaćene kao ostvarivanje predviđenog odgojno-obrazovnog plana i programa. Slunjski (2011a) napominje da je realizacija plana rada bila pretpostav- 
ljena procesu razvoja, odgoja i učenja djeteta te je odgojno-obrazovni proces, umjesto na dijete, bio fokusiran na odgojitelja. Nadalje, tvrdi se (Slunjski, 2011a) da je tradicionalni odgojitelj podređivao dijete sadržaju učenja. Suvremen odgojitelj, za razliku od tradicionalnog, umjesto sadržaja učenja planira materijale kojima će posredno odrediti situacije učenja (Slunjski, 2011b). Navodi se da što je ponuđeni materijal bolje pedagoški osmišljen, dvojba djece o mogućnostima njegova korištenja je manja, a odgojno-obrazovni potencijal aktivnosti veći (Slunjski, 2011b). Važno je zamijetiti kako suvremeni pedagoški koncept tumači da je odgojiteljevo planiranje materijala nužno za osiguravanje razvojne dobrobiti djeteta te $u$ isto vrijeme zaključuje o motivaciji tradicionalnog odgojitelja navodeći da je njegovo planiranje i realiziranje odgojno-obrazovnih sadržaja bilo pretpostavljeno procesu razvoja, odgoja i učenja djeteta.

Kako je navedeno, suvremeni pedagoški koncept naglašava da istraživačke aktivnosti djeca samoorganiziraju i samoiniciraju (Slunjski, 2011a). Slunjski (2011c) zamjećuje da vrtićka djeca u svojim samoiniciranim i samoorganiziranim aktivnostima iskazuju znanja kojima ih nitko nije izravno poučavao. Također navodi da kvalitetno koncipiran odgojno-obrazovni proces omogućuje razvoj organizacijskih kompetencija djece, koje se odnose na njihovu sposobnost osmišljavanja, iniciranja i organiziranja vlastitih aktivnosti (Slunjski, 2011). Zanimljivo je primijetiti da suvremena paradigma ranog i predškolskog odgoja i obrazovanja termin 'igra', učestalo korišten u tradicionalnom pedagoškom konceptu, zamjenjuje terminima samoorganizirane, samomotivirane ili samoinicirane aktivnosti. Primjerice, Program odgojno-obrazovnog rada u dječjem vrtiću (1971) navodio je da je igra osnovna aktivnost $\mathrm{i}$ forma odgojno-obrazovnog rada s djecom predškolske dobi te je igru opisao kao osnovni, najprirodniji i najznačajniji oblik aktivnosti djeteta. Tradicionalni odgojitelj je aktivnom uključenošću rukovodio igrama djece, ali i indirektno sudjelovao u njihovim stvaralačkim igrama. Nasuprot tome, suvremeni koncept sklon je navođenju samoiniciranih, samomotiviranih, samoorganiziranih aktivnosti, istraživačkih aktivnosti ili rada na projektu kao najboljih metoda učenja djece. Usmjeravanjem na samoorganizirane aktivnosti suvremeni koncept ranog i predškolskog odgoja i obrazovanja upućuje na poželjnu uloga odgojitelja. Naime, kako je prethodno istaknuto, govori se o indirektnom sudjelova- 
nju odgojitelja u dječjim aktivnostima. Nacionalni kurikulum za rani $i$ predškolski odgoj i obrazovanje (2014) napominje da se dijete razvija u poticajnom socijalnom i fizičkom okruženju vrtića, u interakciji s materijalima i drugom djecom te uz neizravnu potporu odgojitelja. Takav je pristup u skladu s konstruktivističkim poimanjem znanja koje tumači da je znanje rezultat subjektove individualne aktivnosti konstruiranja, a ne proizvod koji je izvan spoznavatelja i koji se može predati ili instalirati putem percepcije ili lingvističke komunikacije (Glasersfeld, 1990, prema Babić, 2007). Međutim, pojedini autori problematiziraju shvaćanje prema kojem nedirektivna pedagogija podrazumijeva ukidanje poučavanja i transformiranje uloge učitelja u organizatora okoline za učenje, a učenika u autodidakta (Bašić, 2015). Navodi se da je direktna uključenost odraslog u djetetovu aktivnost poželjna jer dijete mehanizme metakognitivne kontrole, potrebne za samostalno učenje, stječe upravo u interakciji s odraslim pojedincima (Gojkov, 2009). Odrasli pomažu djetetu da ono postane svjesno vlastitih misaonih kapaciteta. Konstruktivisti previđaju činjenicu da se učenje koncepata i procedura ne događa urezivanjem novih informacija u stečeno znanje, već je prethodno znanje prepreka na kognitivnom i emotivnom planu. Dijete se naime teško odriče vlastitih interpretativnih koncepata te ih teško dekonstruira i zamjenjuje novima (Gojkov, 2009). Pokazuje se također da stupanj uključenosti odgojitelja u dječju igru pozitivno utječe na složenost i kreativnost dječje aktivnosti (Kontos et al., prema Klarin, 2017). Zanimljivo je, međutim, da u istraživanju u kojemu su se djeca sama izjašnjavala o svojem doživljaju igre, odgojitelje nisu navodila kao sudionike igre (Rajić i Petrović-Sočo, 2015).

Suvremeni pedagoški koncept ističe da je tradicionalni plan i program rada bio usmjeren na činjenično znanje i osobito na kognitivno područje djetetova razvoja (Petrović-Sočo, 2009a), premda su se Programom odgojno-obrazovnog rada u dječjem vrtiću (1971) naglašavali fizički, umni, moralni i estetski odgoj kao ravnopravne kategorije. Iako suvremeni koncept ranog i predškolskog odgoja i obrazovanja primjećuje da je onaj tradicionalan tendirao kognitivnom razvoju, upravo se suvremen odgojno-obrazovni model koncepcijski zasniva na spoznajnoj teoriji, konstruktivizmu, koji čak postaje i paradigma didaktike, što pojedini autori smatraju spornim (Palekčić, 2002). Učenje je središnji pojam suvremenog pedagoškog koncepta. Kako je već napomenuto, su- 
vremeni autori naglašavaju istraživačku prirodu djetetova učenja, zbog čega djecu neki uspoređuju sa znanstvenicima (Gopnik et al., 2003, prema Slunjski, 2011a). Suvremena paradigma aktualizira koncepciju učenja koja je, između ostalog, značajna u motiviranju djece što mlađe dobi za sadržaje prirodnoznanstvenog i matematičkog područja (Milotić, 2013). Pritom se zamjećuje podudarnost dječjih aktivnosti sa znanstvenim istraživanjem. Zanimljivo je da suvremena pedagoška paradigma ističe istraživačke aktivnosti djeteta kao svoj specifikum, premda je djetetovo bavljenje takvim aktivnostima spontano s obzirom na to da je dijete nespecijalizirano i nedeterminirano biće koje ne nasljeđuje gotove obrasce ponašanja pa su njegove istraživačke aktivnosti prirodan način ovladavanja i fizičkom i socijalnom okolinom (Duran, 2003).

Suvremeni odgojitelj odmiče od »tromog« znanja (Renkl, 1996, prema Palekčić, 2014) te se zalaže za performativno znanje na kojemu se bazira koncept kompetencije. Kompetencija je središnji termin suvremene pedagoške paradigme. Kompetencija, kao sveukupni zbir znanja, vještina, razumijevanja, vrijednosti, stavova i zahtjeva koji vode efektivnoj ljudskoj akciji u specifičnom području (Deakin i Crick, 2008, prema Supporting Teacher Competence Development, 2013) uvijek je u kontekstu, u relaciji, pragmatična je, ovisi o očitovanju u konkretnoj situaciji (Komar, 2015). Prema Komaru (2015), kompetencija se bazira na shvaćanju postmodernog znanja kao onog koje odbacuje objektivitet istine, a priklanja se funkcionalnom, efektnom i efikasnom znanju. Znanje je znanje ako djeluje, funkcionira, moćno tehnički i tehnološki proizvodi (Komar, 2015). Novalić (2003) ukazuje na raširenost stava da ljudsko mišljenje i spoznaja imaju svoju vrijednost samo ako služe kao sredstva za praktična životna rješenja (Novalić, 2003). U takvom kontekstu, kako navodi Komar (2005), humanističke znanosti gube na važnosti i percipiraju se kao suvišne s obzirom na to da ne mogu biti podređene kriteriju performativnosti. S druge strane, prirodne i tehničke znanosti postaju paradigmom čime se, kako ističe Novalić (2003), um reducira na dimenziju djelovanja i korisnosti. Uz umanjivanje značajnosti humanističkih znanja, marginalizira se i umjetnički odgoj. U dokumentu Smjernice za umjetnički odgoj (2006) tako se navodi da se u suvremenom obrazovnom procesu dominantno naglašavaju intelektualne sposobnosti, dok se emocionalno područje zanemaruje, što se razotkriva kao jedan od čimbenika propadanja moralnoga ponašanja u 
suvremenom društvu. U tom smislu postoje istaknute intencije afirmiranja umjetničkog odgoja (Smjernice za umjetnički odgoj, 2006).

Generalno razmatrano, opisujući suvremenu pedagošku paradigmu i njoj adekvatnog odgojitelja, autori navode njihovu primjerenost za razvoj djece, ukazujući primarno na različitost u odnosu na tradicionalni pristup. No stav da je praksa suvremenog odgojitelja nadmoćna u odnosu na onu tipičnu za tradicionalnog pedagoškog djelatnika ne može proizlaziti samo iz njihove različitosti. Jednako tako, nedostatno je da se sama promjena pedagoške paradigme, pa time i slike poželjnog odgojitelja, određuje kao cilj pedagoškog koncepta, kada ona zapravo predstavlja tek prvi korak u propitivanju njezine prikladnosti u odnosu na zadaće koje su joj namijenjene.

\section{Implicitna pedagogija i refleksivna praksa}

Implicitna pedagogija predstavlja sustav vrijednosti o djetetovoj naravi, njegovim potrebama i mogućnostima, činiteljima njegova razvoja, o ciljevima odgoja te primjerenim i mogućim odgojnim postupcima (Babić et al., 1997). Karakterizira ju laičnost, nekoherentnost te teorijska neelaboriranost. Njezino je podrijetlo moguće promatrati kao individualni self konstrukt i/ili kao rezultat kolektivne mudrosti nekog društva (Goodnow, 1988, prema Babić et al., 1997).

Govoreći o implicitnoj pedagogiji, Miljak (1996) navodi da u temeljima odgojiteljeve prakse stoji njegova osobna teorija o djetetu i dječjem vrtiću, mogućnostima učenja i poučavanja, kao i odgoja i obrazovanja djece u institucijskom kontekstu. Navedeno se, između ostalog, potkrepljuje istraživanjima o razvoju govora djece rane dobi. Objašnjava se kako očekivanja majke o djetetovim mogućnostima usmjeravaju njezina ponašanja i postupke prema djetetu te su rezultati koje dijete postiže u skladu s majčinim očekivanjima (Lock, 1980, prema Miljak, 1996). Nadalje se navodi da su u sklopu implicitne pedagogije važne »ideje roditelja« o djetetu koje podrazumijevaju predodžbe, sheme, scenarije koje ljudi izgrađuju tumačeći narav socijalnog svijeta u kojemu žive (Goodnow, 1988, prema Babić et al., 1997). Ono što je u navedenom obrazlaganju implicitnih pedagogija značajno primijetiti jest poistovjećivanje roditeljske prakse s praksom odgojno-obrazovnih institucionalnih djelatnika. Za razliku od roditeljske prakse koja 
se očekivano temelji na implicitnoj, osobnoj teoriji, za pretpostaviti je da će odgojno-obrazovni stručni kadar društvenih institucija svoju praksu dominantno bazirati na znanstveno-stručnom modelu djelovanja. Neopravdano je podrazumijevati kako su odgojno-obrazovni ciljevi i odgojni postupci odgojitelja-stručnjaka temeljeni na njihovoj privatnoj odgojnoj koncepciji. Stav da odgojitelj svoju praksu zasniva na vrijednostima koje nije propitao, uvjerenjima koje nije razmotrio, vjerovanjima koja nije osvijestio ili stavovima koje nije stručno i znanstveno potkrijepio, znatno obespravlja odgojitelje kao obrazovan kadar stručno pripremljen za odgojno-obrazovne zadaće u ustanovama ranog i predškolskog odgoja i obrazovanja. U širem kontekstu promatrano, dignitet same pedagogije kao autonomne znanosti opterećen je stavom da pedagogija, s obzirom na to da se bavi odgojem i obrazovanjem, zahvaća jednu univerzalnu ljudsku djelatnost, nešto što svi prakticiraju, mnogi čak i vrlo uspješno bez ikakvih teorijskih znanja i formalne izobrazbe (Sekulić-Majurec, 2007). Iz takvog tumačenja proizlazi kako odgoj i obrazovanje možemo odrediti kao vještinu, umješnost ili umijeće koju neki ljudi posjeduju, a neki naprosto ne (Sekulić-Majurec, 2007). Mužić (1999) naglašava da teorija odgoja i obrazovanja ima svoje znanstvene aspekte, kao i one koji se ne svrstavaju u znanost. No, opravdano je očekivati da odgojno-obrazovni djelatnici, za razliku od roditelja, zasnivaju svoje stručno djelovanje na osviještenim znanstvenim pretpostavkama čime se priznaje stručni identitet pojedinaca uključenih u odgojno-obrazovni rad.

Mnogi autori (Petrović-Sočo, 2009) upućuju na važnost odgojiteljeve implicitne pedagogije, tumačeći kako je ona preduvjet načina organiziranja cjelokupnog odgojno-obrazovnog konteksta. Navodi se da odgojiteljevo povjerenje u dijete, koje se očituje u čitavoj odgojno-obrazovnoj strukturi (prostorno-materijalnom kontekstu, organizacijskoj i vremenskoj strukturi, odnosima i komunikaciji unutar zajednice) proizlazi iz njegovih uvjerenja, vrijednosti i stavova (Slunjski, 2008, prema Bucković et al., 2015). Obrazlaže se da implicitna pedagogija djeluje na strukturiranje vremena i prostora, izbor materijala i aktivnosti te narav interakcije odrasli-dijete (Babić i et al., 1997). Konkretno, opisujući prostor tradicionalne odgojno-obrazovne ustanove, navodi se da se on uređuje, organizira i koristi kao posljedica odgojiteljevih stavova, uvjerenja, očekivanja i vrijednosti (Petrović-Sočo, 2009). No 
stavovi, uvjerenja, očekivanja i vrijednosti tradicionalnog odgojitelja uvjetovani su ponajprije odgojiteljevim društvenim obrazovanjem u duhu biheviorističkog psihološkog pristupa učenju i širih društvenih vrijednosti socijalističkog doba. Po jednakom se principu suvremena odgojno-obrazovna ustanova formira u skladu s konstruktivističkim pristupom učenju i društvenim vrijednostima kapitalističkog razdoblja. Navedeno je razumljivo s obzirom na to da su intencionalni ciljevi odgoja u odgojno-obrazovnim ustanovama nužno povezani sa socijalizacijom u širem kontekstu koja utječe na sve odgojne činitelje usmjerene na dijete. Razumijevanje cjelovitog znanstvenog i društveno-političkog konteksta u kojemu odgojno-obrazovni djelatnici provode pedagošku praksu potrebno je zbog izbjegavanja predimenzioniranja i isključivog prikazivanja odgojiteljeve privatne odgovornosti za karakter prakse. Također, tumačenje kako je organizacija odgojno-obrazovnog procesa ovisna o razini povjerenja koju odgojitelj upućuje djetetu ukazuje na važnost interpretacije pojmova poput povjerenja, slobode, emancipacije, fleksibilnosti ili tolerantnosti. Velika pojmovna neodređenost odlika je pedagogije kao takve pa ako pedagoška polazišta, uvjete i ciljeve pojašnjavamo nedovoljno konkretiziranim apstraktnim pojmovima koji su sadržajno nejasno određeni, neizbježni su nesporazumi u komunikaciji i interpretaciji prakse. U tome je smislu osobito važno pobliže odrediti značenje sintagme 'povjerenje u dijete'.

Pitanje pedagoškog povjerenja često se predstavlja kao pitanje odgojiteljeva osobnoga opredjeljenja, njegova subjektivna stava, privatnoga mišljenja i vlastite odgojne teorije. Ipak, navedeno je pitanje u pedagoškom diskursu često polemizirano. Naime, analiza dokumenata o pravima djece pokazuje da su u njima najzastupljeniji iskazi koji se ubrajaju u sferu zaštite djeteta, iz čega proizlazi da se djeca dominantno smatraju ranjivima, a djetinjstvo se predstavlja kao razdoblje u kojemu je za dječju dobrobit najvažnija uloga odraslih (Kopić i Korajac, 2010). No istovremeno se $\mathrm{u}$ istim dokumentima izražava važnost djetetove autonomije i njegova prava na aktivno sudjelovanje u društvu što ukazuje na to da su brojni iskazi u dokumentima o pravima djece proturječni (Kopić i Korajac, 2010). Drugi autori pojašnjavaju dva koncepata pristupa djetetu, promatrana kroz diskurs o djetetovim potrebama ili o njegovim pravima (Stainton Rogers, 2009, prema Polić P., 2015). Diskurs o djetetovim potrebama polazi od uvida iz razvojne psihologije. Ovim 
konceptom promovira se shvaćanje djece kao psihološki i emocionalno ovisne i ranjive, s potrebom za određenim iskustvima i prilikama (Stainton Rogers, 2009, prema Polić P., 2015). Diskurs o djetetovim pravima preklapa se sa socijalno-konstruktivističkim shvaćanjem djeteta i djetinjstva koje naglašava da su djeca nositelji vlastitih prava te da je potrebna njihova aktivna participacija u svim stvarima koje ih se tiču (Polić P., 2015). Upravo se od pedagogije očekuje opredjeljivanje prema ovom pitanju u vidu integriranja navedenog psihološkog i sociološkog razumijevanja.

Usporedno s isticanjem važnosti implicitne pedagogije u radu odgojitelja, naglašava se i značaj refleksivne prakse kojoj je cilj da se odgojiteljeva teorija o praksi svjesno spoznaje i jasno artikulira. Slunjski (2011) napominje da veliku smetnju razvoju kvalitetne odgojno-obrazovne prakse čini odgojiteljeva nerealna procjena karakteristika takve prakse. Refleksivna praksa potiče učiteljevo kritičko promišljanje o sebi i svojem djelovanju kako se ono ne bi temeljilo na predrasudama i zastarjelim razmišljanjima (Ferguson, 2012, prema Bilač, 2015).

Jedan od teorijskih modela refleksivne prakse (Osterman i Kottkamp, 2004, prema Bilač, 2015) bazira se na Kolbovom modelu iskustvenog učenja koji obuhvaća fazu konkretnog iskustva, promatranja i analiziranja, rekonceptualiziranja i aktivnog eksperimentiranja. No, neposredno odgojiteljevo iskustvo kojim, prema Kolbovu modelu, započinje proces iskustvenog učenja nije slučajan pokušaj, nasumično praktično rješenje, proizvoljno odabran čin baziran na neosviještenim pretpostavkama kojima tumačimo odgojno-obrazovnu zbilju. Odgojitelj ne sudjeluje u svojoj odgojno-obrazovnoj praksi osobno neosviješten, subjektivno predisponiran, stručno nepripremljen, profesionalno onesposobljen. Potrebno je naglasiti da iskustveno učenje u tome smislu ne započinje konkretnim iskustvom, već znanjem, na temelju kojega se iskustvo planira. Reflektiranje prakse i aktivno eksperimentiranje moguće je samo tada kada odgojitelji raspolažu potrebnim znanjima, stručnim vještinama, osobnim sposobnostima i individualnim kapacitetima stečenima i razvijanima kroz kontinuirano obrazovanje koje ih legitimira kao stručnjake prakse. Stoga je u pedagoškom kontekstu mnogo primjenjiviji model iskustvenog učenja kojim se pretpostavlja refleksija prije akcije kao značajna razina u procesu refleksivnog učenja (Cowan, 1998, prema Vizek Vidović i Vlahović-Štetić, 2007). 
Iako je u procesu razvoja refleksivne prakse važnost odgojiteljeva znanja neupitna, neki autori relativiziraju značajnost spoznaja na razini teorije, napominjući kako danas postoji niz istraživanja koja potvrđuju da spoznaje ionako ne mijenjaju ponašanje (Palekčić, 1998, prema Sekulić-Majurec, 2007). Objašnjava se da je odgojno-obrazovna praksa previše trom i ustaljen, suviše tradicionalan sustav da bi se mogao promijeniti samo poučavanjem praktičara o nekim novim spoznajama (Miljak, 2005, prema Sekulić-Majurec, 2007). Slunjski i Burić (2014) obrazlažu da se službene teorije teško implementiraju u praksu s obzirom na to da ih praktičari površno razumiju ili pak ne prepoznaju teoriju koja upravlja njihovom praksom. No, važno je naglasiti da ishodiše mnogih pedagoških reformi uopće niti nisu nove pedagoške spoznaje. Miljak (2005) napominje da vlade različitih zemalja usmjeravaju odgojno-obrazovne reforme u skladu s općom politikom, iako često izostaje evidencija o znanstvenim istraživanjima koja su imala utjecaj na politiku reforme. $U$ tome je smislu ponajprije važno naglasiti da odgojno-obrazovni sustav ne bi smio postati društveni sektor podređen potrebama političkih ostvaraja u društvenom aktualitetu.

No, ako i uvažimo prethodno navedeno te pretpostavimo da spoznaje neće direktno mijenjati ponašanje, one se ipak mogu smatrati osnovom za promjenu ponašanja. Autentične spoznaje pedagogije kao autonomne znanosti itekako mogu utjecati na odgojiteljevo djelovanje u slučaju da ih on kritički procesuira, praktično validira i temeljem toga akceptira. Ako odgojitelju nisu jasne teorijske razložbe pedagogije ili srodnih znanosti kojima se određuje karakter odgojno-obrazovnih praktičnih nastojanja, onda su ona rezultat nasumičnih isprobavanja, slučajnih subjektivnih procjena, nerazrađenih ideja, osobnih nahođenja i posljedica za koje ne možemo utvrditi pojavljuju li se akcidentalno ili kao pravilnost. Kada odgojitelju nisu jasne stručno-teorijske pretpostavke na kojima on zasniva vlastiti rad - a navodi se da su za spoznaje prezentirane na znanstveno-stručnim skupovima odgojitelji često zakinuti te da je transmisija znanstvenih spoznaja u praksu prilično ograničena (Sekulić-Majurec, 2007) - tada je njegova djelatnost stvar osobne proizvoljnosti ili društvene manipulacije. U tome je smislu umjesto umanjivanja važnosti teorijskih pretpostavki važno težiti njihovom komplementarnom nadopunjavanju s praktičnim djelovanjem. 


\section{Akcijska istraživanja - teorijska određenja i praktična ostvarenja}

Suvremena pedagoška paradigma ističe akcijska istraživanja kao optimalnu metodu istraživanja i unaprjeđivanja neposredne odgojno-obrazovne prakse. Akcijska istraživanja podrazumijevaju empirijske, neeksperimentalne studije socijalne situacije s ciljem unaprjeđivanja prakse i kvalitete njezina razumijevanja (Winter i Munn-Giddings, 2001, prema Visković, 2013). Deskriptivna su metoda jer im je primarna svrha razumijevanje određenih fenomena (Mužić, 1999). Smatra se da predstavljaju varijantu razvojnih istraživanja jer se njima unose novosti u odgojno-obrazovnu djelatnost $i$ to na temelju njihove znanstvene provjere (Mužić, 1999). Glavnim značajkama akcijskih istraživanja smatraju se provedba realizirana od neposrednih sudionika odgojno-obrazovnog procesa, fleksibilnost, timski rad i empiričnost procesa. Akcijskim istraživanjima teži se razumijevanju aktualne pedagoške prakse kako bi se osmišljenim strategijama djelovanja koje se implementiraju u odgojno-obrazovni proces mogle razumjeti i pravilno evaluirati postignute promjene.

Akcijska istraživanja javljaju se kao istraživačka metodologija kritičke teorije. Kritička znanost o odgoju suprotstavlja se biheviorističkoj znanosti, na kojoj se temelji tradicionalan pristup odgoju i obrazovanju, kao i duhovnoznanstvenoj pedagogiji (Konig i Zedler, 2001). Težnja kritičke znanosti nije samo povećanje znanja nego i oslobođenje čovjeka iz porobljavajućih odnosa (Horkheimer, 1988, prema Konig i Zedler, 2001). Kritička znanost afirmira se 1960-ih godina, nakon Drugog svjetskog rata tijekom kojeg su se pedagoška nastojanja umnogome podčinila fašističkom i nacističkom usmjerenju. Budući da je tada cjelokupno društvo bilo talac određenog autoriteta, uslijedilo je razdoblje koje je upućivalo na važnost autonomije individue koja se manifestira u pojedinčevoj snazi razmišljanja, mogućnosti samoodređenja, odbijanju sudjelovanja (Adorno, 1997, prema Konig i Zedler, 2001). Kao temeljne vrijednosti društava u europskom kulturnom okruženju izdvajaju se sloboda i subjektivnost koje podrazumijevaju individualizam, pravo kritike, autonomiju djelovanja te idealističku filozofiju (Habermas, 1988, prema Bognar, 2017). Naglašava se da odgojno-obrazovni sustav više ne smije biti replika društvene politike kojom se usustav- 
ljaju odnosi koji sprječavaju ljudsko samoodređenje. Izražava se zato potreba dokidanja autoriteta kao prepreke emancipaciji što, na razini odgojno-obrazovnog odnosa, podrazumijeva ukidanje odgojnog autoriteta odgojitelja (učitelja). Pojam autoriteta u suvremenoj pedagoškoj paradigmi postaje problematiziran. Suvremena pedagoška paradigma poziva na oslobađanje djeteta od zavisnosti o odraslima, promovira djetetovo samoodređenje i zahtijeva njegovu autonomiju (Bašić, 2009) te se učestalo argument »dijete želi« izjednačava s izborom »za djetetovo dobro« (Bašić, 2005, prema Bašić, 2009). Vranješević (2005) ukazuje na potencijalni konflikt shvaćanja odnosa participacije učenika i autoriteta nastavnika u odgojno-obrazovnom procesu premda se, zapravo, preciznijim čini tematizirati suodnos participacije djece i odgovornosti odraslih u procesu institucionalnog odgoja i obrazovanja.

Kao razlog široke primjene pedagoških akcijskih istraživanja, osobito krajem 20. stoljeća, autori navode uvid da velika reformska nastojanja u odgojno-obrazovnoj sferi ne doprinose mnogo stvarnim promjenama u školama (Hollingsworth i Sockett, 1994, prema Bognar, 2009). Promjene koje su školi potrebne proizlaze iz konkretnih problema s kojima se učitelji susreću u svome djelovanju, a čija rješenja vrlo rijetko dolaze iz akademskih ustanova ili instituta za istraživanje, dakle učitelji ih najčešće osmišljavaju sami (Bognar, 2009). Preduvjet učiteljevih originalnih rješenja njegova je kreativnost. Bitne karakteristike kreativnog učitelja, poput autonomije misli, inicijativnosti, intrinzične motivacije, žudnje za slobodom i sposobnosti kritičkog promišljanja (Ozimec, 1996, prema Tischler, 2007) proizlaze upravo iz vrijednosti koje akcijsko istraživanje afirmira. Općenito, suvremena pedagoška paradigma tendira učitelju koji nije marginaliziran u prosvjetnom sustavu. Tako se, primjerice, učitelja ne upućuje direktivno na određene forme stručnog usavršavanja, nego njegova vlastita težnja za stručnim napredovanjem proizlazi iz njegove potrebe samorazvoja osobnosti (Tischler, 2007).

Nakon izloženog, potrebno je uvidjeti kako se teorijsko-koncepcijska ideja akcijskih istraživanja konkretno provodi i praktično realizira. $\mathrm{U}$ tu svrhu možemo analizirati opise akcijskih istraživanja provedenih u ustanovama ranog i predškolskog odgoja na prostoru Republike Hrvatske, predstavljenih u relevantnoj pedagoškoj literaturi. Iako su se neka od navedenih istraživanja provodila početkom 90 -ih godina 20 . stoljeća, veoma su značajna jer predstavljaju temelj pristupa pedagoškim pi- 
tanjima u aktualnom pedagoškom konceptu, a autori koji su sudjelovali u njihovoj provedbi predstavljaju autoritete na čijim se radovima zasniva aktualan odgojno-obrazovni koncept vezan uz rani i predškolski odgoj i obrazovanje.

U istraživačkim prikazima akcijskih istraživanja često se ukazuje na odgojiteljevu nekompetentnost kroz prikazivanje njegova neznanja, upućivanje na njegovo elementarno nerazumijevanje pedagoških pitanja te iskazivanje manjkavosti njegovih praktičnih postupaka. Navedeno je veoma zanimljivo s obzirom no to da su se neka istraživanja (poput Miljak, 1996) provodila u razdoblju kada se, s velikim društvenim promjenama, tek naznačuju promjene očekivane u odgojno-obrazovnom sustavu. Istraživači, koji nisu neposredni sudionici odgojno-obrazovnog procesa, izlažu kako im je namjera istražiti i promijeniti praksu, preobraziti je od tradicionalne ka suvremenoj. No, pritom naglašavaju kako njihova uloga nije stare teorijske osnove zamijeniti novima, nego omogućiti praktičarima da relativno samostalno reguliraju svoje aktivnosti (Šagud, 2002). Pojašnjava se kako odgojiteljevo samostalno reguliranje aktivnosti podrazumijeva kako istraživači ne nameću ciljeve praktičarima već se usmjeravaju na suradnju s neposrednim provoditeljima odgojno-obrazovnog rada (Šagud, 2002). No, u prikazu akcijskog istraživanja vezanog uz uspostavu komunikacije djeteta i odgojitelja prilikom čitanja slikovnice (Petrović-Sočo, 1997) navodi se kako je, nakon zajedničke analize snimke odgojitelja u aktivnosti s djecom, istraživač predložio odgojitelju da pokuša primjenjivati postupke kojima potiče djetetov prijevod vizualnog u verbalni kod, da inicijativu za uspostavljanjem komunikacije češće prepusti djeci, da primjerenije reagira na dječje verbalne izričaje te da obogati prostorno-materijalni kontekst. U daljnjem tijeku istraživanja istraživač zamjećuje da odgojitelj nastoji primijeniti njegov prijedlog o kvalitetnijem poticanju prijevoda vizualnog koda u govorni (Petrović-Sočo, 1997). Odgojitelja zapravo istraživač metodički usmjerava i upućuje na kriterije uspješnosti promatrane aktivnosti. Prosudba istraživača o poželjnim i nepoželjnim odgojiteljevim ponašanjima, odnosno procjena metodičkih postupaka uz direktno upućivanje na poželjno djelovanje, zamjetljiva je i u prikazu drugih akcijskih istraživanja. Tako primjerice neki istraživači prilikom promatranja odgojiteljeve prakse klasificiraju njegova »vrlo dobra« i »vrlo loša« ponašanja koja se sadržajno opisuju i odjeljuju s obzirom 
na predmet istraživanja, konkretno na kvalitetu sudjelovanja odgojitelja u dječjoj igri (Šagud, 2002). Istraživač čak dodjeljuje opću ocjenu pojedinom odgojitelju koji je sudjelovao u istraživanju (Šagud, 2002). Iako iz navedenog proizlazi da se odgojitelja zapravo poučava putem uvježbavanja određenog metodičkog postupka po preporuci i očekivanju istraživača, istovremeno se u teorijskim razložbama o djelovanju odgojitelja naglašava da se njegov kompetencijski pristup u praksi ne bi trebao temeljiti na predlošku tradicionalnog obrazovanja odgojitelja čije profesionalne kompetencije čine uvježbani postupci, stereotipi i obrasci (Šagud, 2011).

Istraživači zamjećuju (Petrović-Sočo, 2009) da prilikom provedbe akcijskih istraživanja povremeno dolazi do njihova nerazumijevanje $s$ praktičarima. No, također navode i kako ih primjerice odgojiteljevo nerazumijevanje samoučenja djeteta (kao metode učenja) ne obeshrabruje jer vjeruju da će s vremenom odgojitelji »olabaviti« i smanjiti strah od novog i nepoznatog (Petrović-Sočo, 2009, 130). Ipak, ovdje je važno naglasiti da je ishodište nepodudarnosti u razumijevanju odgojitelja i istraživača u razlici između bihevioristički obrazovanih odgojitelja i konstruktivistički usmjerenog istraživača koji zapravo predstavljaju drukčije pedagoške orijentacije, nepodudarne interpretacijske zone, različita teorijska ishodišta bazirana na različitim empirijskim validacijama iz drukčijeg vremenskog konteksta. Kao jedan od kriterija uspješno provedene akcije akcijskih istraživanja, pojedini autori (Bognar, 2006) ističu aktivno bavljenje ciljevima i posljedicama. Pitanje je koliko je navedeno ostvarivo ako nije postignut konsenzus o paradigmatskom okviru kroz koji se praksa promatra i tumači.

Uslijed međusobnog nerazumijevanja odgojitelja i istraživača tijekom provedbe akcijskih istraživanja, a kroz situacije u kojima su odgojitelji izloženi doživljaju vlastite neadekvatnosti za namijenjene stručne zadaće, zamjećuje se da njihova entuzijastična motivacija za ovladavanjem novim vještinama i širenjem spoznaja rapidno opada. Šagud (2002) opisuje kako zbog nemogućnosti odgojitelja da sugestije istraživača praktično provede, u određenim epizodama istraživanja on postepeno odustaje od bilo kakvih intervencija tijekom dječje igre koja je bila predmet izučavanja (Šagud, 2002). Petrović-Sočo (1997) zamjećuje da u pojedinim fazama istraživanja odgojitelj pokazuje da se ne osjeća uspješnim, a istraživač pretpostavlja kako je, uz eventualnu 
odgojiteljevu samospoznaju, tome pridonio i on sam pa nastoji povratiti odgojiteljevo samopouzdanje kako bi s više motivacije sudjelovao u daljnjim akcijama istraživanja (Petrović-Sočo, 1997). Nemogućnost odgojiteljeve praktične provedbe sugestija istraživača potencijalno proizlazi iz nedovoljno sustavno objašnjenih prijedloga koji su, iz perspektive odgojitelja, mentalno neproživljeni, intelektualno nerazrađeni, svjesno nekonceptualizirani. Ako se društvo suočava s odgojno-obrazovnim reformama i potrebom značajnijeg mijenjanja odgojno-obrazovne prakse, kao primjerice u hrvatskom društvu početkom 90-ih godina 20. stoljeća, onda je odgojitelje potrebno sustavno i organizirano uvesti u teorijske koncepte i vrijednosne okvire koji su ishodište nove poželjne prakse, uz razjašnjavanje metodičkih oblika rada i didaktičkih strategija. No, neovisno o tome radi li se o velikim reformskim promjenama odgojno-obrazovnog sustava na društvenoj razini ili specifičnima inovacijama na razini pojedine ustanove ili odgojno-obrazovne skupine, važno je naglasiti da će pojedinac, surađujući sa su-stručnjacima, uključiti nove informacije u svoj osobni sustav vrijednosti i spoznaja samo ako ih ne percipira kao prijetnju svom osobnom integritetu (Vizek Vidović i Vlahović-Štetić, 2007).

Prikazane uloge istraživača u akcijskim istraživanjima su raznolike, no mogu se sistematizirati u nekoliko tipova. Ponajprije, neki autori zastupaju tezu kako bi inicijatori akcijskih istraživanja trebali biti oni koji nisu neposredni provoditelji odgojno-obrazovne prakse. Tako Petrović-Sočo $(1997,18)$ navodi da bi poticaj za pokretanje promjena u odgojno-obrazovnoj praksi u hrvatskim pedagoškim uvjetima trebao dolaziti od pedagoga. Nadalje obrazlaže da tek uz pomoć pedagoga odgojitelj stječe sposobnost samorefleksije vlastite prakse te je stoga važno da pedagog ima uvid u eksplikaciju implicitnih pedagogija odgojitelja (Petrović-Sočo, 1997). Stajalište da učitelji mogu lako preuzeti ulogu kritičkog prijatelja i akcijskog istraživača pojedini autori smatraju nerealnim očekivanjem, svojevrsnom predrasudom (Bognar, 2011). Takvi se stavovi javljaju istovremeno s onima koji ističu da je odgojitelja važno uvažiti kao onoga koji inicira i provodi promjene u odgojno-obrazovnoj djelatnosti (Tischler, 2007). Dapače, navodi se da se promjene u odgojno-obrazovnoj praksi ne mogu pokrenuti reformama ako učitelji nisu njihovi inicijatori (Bilač, 2015). 
Uz inicijatora, istraživač se često realizira i u ulozi prosuditelja odgojiteljeve djelatnosti, primjerice: »Prema onome što smo vidjeli na snimci, odgajateljice imaju povjerenja u dječje sposobnosti« (Miljak, 1996, 103). Na temelju ponašanja (što je inače bihevioristička osnova zaključivanja) istraživač prosuđuje o odgojiteljevim pretpostavkama rada. Uz prosuditelja, istraživač je često i u ulozi ocjenjivača, poput: »Mogli bismo reći da odgojiteljice zadovoljavaju postavljene kriterije odnosa prema djeci« (Miljak, 1997, 103). On je i presuditelj: »Očito je bilo teško naći argument koji bi osporio uspjeh ove djece i odgojiteljica, a istodobno je učinio bespredmetnom svu navedenu argumentaciju kolegica« (Miljak, 1997, 113). Povremeno je i osuditelj: »Konačno je mentorici ove odgojiteljice dosadila ovakva njena uloga i jednostavno ju je maknula sa scene i prepustila da djeca sama rade« (Miljak, 1996, 85). Istraživač je i opći evaluator: »Odgajatelji ne znaju procijeniti uspješnost aktivnosti« (Miljak, 1996, 87). Samostalno objašnjavajući svoju ulogu, istraživači tumače da se ona može poistovjetiti s ulogom odgojitelja prema djetetu - kao što je odgojitelj pomagač i voditelj djeteta u odgojno-obrazovnom procesu, tako je istraživač pomagač i voditelj odgojitelju u istraživanju odgojno-obrazovne prakse (Miljak, 1996). Prethodno navedeni prikazi nisu u suglasju s deklaratornim stavom koji naglašava kako nova znanstveno-teorijska razmišljanja pretpostavljaju osnaženog i odgovornog profesionalca koji ima dovoljno znanja, umijeća i autonomije za suvereno oblikovanje prakse (Šagud, 2011). Zapisi akcijskih istraživanja svjedoče o tome kako teorijski koncept nije uvijek lako ostvariv poduhvat.

\section{Zaključak}

Suvremena pedagoška koncepcija obiluje proturječnostima postavki i zahtjeva, a svoju valjanost često potkrepljuje pozivajući se na različitosti u odnosu na tradicionalitet. No, drukčije karakteristike u odnosu na tradicionalnu paradigmu još uvijek ne dokazuju adekvatnost suvremenih obilježja. Kako bi suvremeni pedagoški koncept, u svim svojim segmentima pa tako i u onome koji se tiče slike poželjnog odgojitelja omogućio razvoj svojih ideja, pretpostavki, nastojanja i ciljeva, važno je da teži uviđanju vlastitih nedorečenosti i započne kritičku samoevaluaciju radi vlastitog teorijskog i praktičnog napretka. Umjesto 
inzistiranja na sveobuhvatnom distanciranju od tradicionalnog obrasca pedagoške prakse, bilo bi poželjnije težiti njihovoj logičkoj nadgradnji u odgojno-obrazovnom procesu.

Implicitna pedagogija, često predstavljena kao temelj odgojiteljeve prakse, zasniva se na promatranju osobne povijesti odgojno-obrazovnog djelatnika i razumijevanju njegova misaono-vrijednosnog sklopa. Ipak, nezanemarivo je važan i društveno-politički kontekst odgojiteljeva djelovanja, promatran kroz njegovo obrazovanje i institucionalne zahtjeve odgojno-obrazovnih ustanova, što je potrebno uvažavati. U suvremenom naglašavanju nedostatnosti tradicionalnih odgojno-obrazovnih principa važno je napomenuti da su ih primjenjivali odgojitelji koje je obrazovanje i društveno okruženje na njih upućivalo, a koji su se temeljili na određenim znanstvenim pretpostavkama i aktualnim društvenim vrijednostima.

Akcijska istraživanja, dominantna suvremena metoda istraživačke promijene odgojno-obrazovne prakse, predstavljaju se kao ona koja žele služiti rješavanju društvenih, odnosno pedagoško-praktičnih problema te se javljaju kao izraz dosljedne demokratizacije društva i odgoja (Klafki, 1973, prema Konig i Zedler, 2001). Njihova je tendencija da učitelj prestane biti činovnikom i postane osobom odgovornom za svoje osobno napredovanje i napredovanje učenika (Bognar, 2001). Bognar (2001) naglašava da učitelj u kritičko emancipacijskom pristupu nije shvaćen kao tehničar čija je najvažnija zadaća ostvarivanje »društveno« prihvaćenih ciljeva. Međutim, razmatranje ciljnih orijentacija suvremenih odgojno-obrazovnih dokumenata, poput Strategije obrazovanja, znanosti i tehnologije (2014), čini ovu postavku podložnom kritičkom razmatranju, a promatranje izvješća provedenih akcijskih istraživanja pokazuje da se njihove teorijske namjere u praksi tek djelomično ostvaruju.

Tijekom provedbe akcijskih istraživanja, naime, pojedini autori navode da odgojitelji i pored verbalnih upozorenja, pisanih materijala, izravnih priprema i gledanja snimki nisu vidjeli ili nisu htjeli vidjeti svoje pogreške u odgojno-obrazovnoj praksi (Miljak, 1996, 87). Usprkos svoj kompleksnosti cjelokupnog odgojno-obrazovnog konteksta i složenosti situacija, i unatoč opravdanosti pojedinih pedagoških dilema, pojedini istraživači (Miljak, 1996) najčešće će ustvrditi da zapravo odgojitelji nisu u mogućnosti shvatiti svoje vlastite greške. Važno je naglasiti 
kako je u određenim akcijskim istraživanjima izvjesno da odgojitelji i istraživač, ako ne dijele isti koncepcijsko-interpretativni okvir, ne mogu ni postavljati srodne ciljeve u odgojno-obrazovnoj praksi niti tumačiti posljedice djelovanja kroz perspektivu iste pedagoške paradigme. Odgojitelji su općenito skloni evaluirati svoju praksu temeljem svoga obrazovanja kojim stvaraju interpretacijski okvir za procjenu uspješnosti vlastitoga rada. Neovisno inicira li istraživanje vanjski istraživač ili sam odgojitelj, potrebno je da akcijsko istraživanje u pedagoškoj ustanovi u odnosu na neposredne provoditelje odgojno-obrazovnog procesa bude samomotivirano, vlastitim odabirom producirano te kreativno angažirano kako bi odgojitelji, kao stručno afirmiran kadar, kontinuirano doprinosili razvoju vlastite prakse.

\section{Literatura}

Babić, Nada; Irović, Stanislava; Krstović, Jasna (1997), »Vrijednosni sustav odraslih, odgojna praksa i razvojni učinci«, Društvena istraživanja: časopis za opća društvena pitanja, 6(4/5), str. 551-575.

Babić, Nada (2007), »Konstruktivizam i pedagogija«, Pedagogijska istraživanja, 4(2), str. 217-227.

Baranović, Branislava (2006), »Nacionalni kurikulum u europskim zemljama i $\mathrm{Hr}-$ vatskoj: komparativan prikaz«, Sociologija sela, 44(2-3), str. 181-200.

Bašić, Slavica (2009), »Dijete kao partner u odgoju: kritičko razmatranje«, Odgojne znanosti, 11(2), str. 27-44.

Bašić, Slavica (2012), »Kriza djetinjstva«, Dijete, vrtić, obitelj: časopis za odgoj $i$ naobrazbu predškolske djece namijenjen stručnjacima i roditeljima, 18(67), str. $10-12$.

Bašić, Slavica (2015), »Svrha i osnovna obilježja pedagoškog odnosa«, u: Opić, Siniša; Bilić, Vesna; Jurčić, Marko (ur.), Odgoj u školi, Zagreb: Učiteljski fakultet Sveučilišta u Zagrebu, str. 11-45.

Bilač, Sanja (2015), »Refleksivna praksa - čimbenik utjecaja na profesionalni razvoj, mijenjanje odgojno-obrazovne prakse i kvalitetu nastave«, Napredak, 156(4), str. 447-460.

Bognar, Branko (2006), »Kako procijeniti kvalitetu akcijskog istraživanja«, Metodički ogledi: časopis za filozofiju odgoja, 13(1), str. 49-68.

Bognar, Branko (2009), »Učitelji i učenici - akcijski istraživači«, u: Puževski, Valentin; Strugar,Vladimir (ur.), Škola danas, za budućnost, Križevci - Bjelovar: Znanstveno-praktični obzori, str. 195-205.

Bognar, Branko (2011), »Problemi u ostvarivanju suštinskih promjena u praksi učitelja posredstvom akcijskih istraživanja«, u: Kovačević, Dubravka; Ozor- 
lić Dominić, Renata (ur.), Akcijsko istraživanje i profesionalni razvoj učitelja i nastavnika, Zagreb: Agencija za odgoj i obrazovanje, str. 41-60.

Bognar, Branko (2015), »Čovjek i odgoj«, Metodički ogledi, 22(2), str. 9-37.

Bucković, Ivana; Kolarić Piplica, Sanja; Križanac, Valentina (2015), »Razvoj povjerenja u dijete i njegove mogućnosti«, Dijete, vrtić, obitelj: časopis za odgoj $i$ naobrazbu predškolske djece namijenjen stručnjacima i roditeljima, 21(79), str. 19-20.

European Commision (2005), Common European Principles for Teacher Competencies and Qualifications. Dostupno na: http://www.pef.uni-lj.si/bologna/ dokumenti/eu-common-principles.pdf [10. 11. 2019.]

Ćurko, Bruno; Kragić, Ivana (2008), »Filozofija za djecu - primjer Male filozofije«, Život i škola: časopis za teoriju i praksu odgoja i obrazovanja, 54(20), str. 61-68.

Skok, Dobriša (ur.) (2004), Deklaracija o znanju - Hrvatska temeljena na znanju i primjeni znanja (2004), Zagreb: Hrvatska akademija znanosti i umjetnosti.

Državni zavod za zaštitu obitelji, materinstva i mladeži (2001), Konvencija o pravima djeteta, Zagreb: Državni zavod za zaštitu obitelji, materinstva i mladeži.

Duran, Mirjana (2003), Dijete i igra, Jastrebarsko: Naklada Slap.

Gojkov, Grozdanka (2009), Didaktika i metakognicija, Vršac: Visoka škola strukovnih studija za obrazovanje vaspitača »Mihailo Palov«.

Keeley, Brian (2009), Ljudski kapital: od predškolskog odgoja do cjeloživotnog učenja, Zagreb: Educa.

Klarin, Mira (2017), Psihologija dječje igre, Zadar: Sveučilište u Zadru.

Koenig, Eckard; Zedler, Peter (2001), Teorije znanosti o odgoju: uvod u osnove, metode i praktičnu primjenu, Zagreb: Educa.

Komar, Zvonimir (2008), »Pedagogija kao sustavna znanost obrazovanja«, Pedagogijska istraživanja, 5(2), str. 127-136.

Komar, Zvonimir (2015), »Mogućnost odgoja i obrazovanja u kontekstu postmodernog pojma znanja«, u: Opić, Siniša; Bilić, Vesna; Jurčić, Marko (ur.), Odgoj u školi, Zagreb: Učiteljski fakultet Sveučilišta u Zagrebu, str. str. 223-250.

Kopić, Željka; Korajac, Valerija (2010), »Djeca i djetinjstvo u dokumentima o pravima djece«, Život i škola, 24(56), str. 45-54.

Milat, Josip (2007), »Epistemologija pedagogije: dileme, pitanja, moguća rješenja«, Pedagogijska istraživanja, 4(2), str. 189-199.

Milotić, Branka (2013), »Djeca kao znanstvenici - znanstvenici kao djeca«, Dijete, vrtić, obitelj: časopis za odgoj i naobrazbu predškolske djece namijenjen stručnjacima i roditeljima, 19(73), str. 16-17.

Miliša, Zlatko; Dević, Jasminka; Perić, Ines (2015), »Kriza vrijednosti kao kriza odgoja«, Mostariensia: časopis za društvene i humanističke znanosti, 19(2), str. 7-20.

Mijatović, Antun (2000), Leksikon temeljnih pedagogijskih pojmova, Zagreb: Edip. 
Miljak, Arjana (1996), Humanistički pristup teoriji i praksi predškolskog odgoja, Velika Gorica - Zagreb: Persona.

Miljak, Arjana (2005), »Su-konstrukcija kurikuluma i teorije (ranog odgoja) obrazovanja«, Pedagogijska istraživanja, 2(2), str. 235-249.

[MZOS] Ministarstvo znanosti, obrazovanja i sporta RH (2014), Nacionalni kurikulum za rani i predškolski odgoj i obrazovanje, Zagreb: Ministarstvo znanosti, obrazovanja i sporta RH.

Mužić, Josip (2007), »Problem filozofske metode«, Crkva u svijetu, 42(1), str. $155-166$.

Mužić, Vladimir (1999), Uvod u metodologiju istraživanja odgoja i obrazovanja, Zagreb: Educa.

Nimac, Elvira (2011), »Primjena Bloomove taksonomije znanja u nastavi«. Dostupno na: http://www.azoo.hr/images/razno/E._Nimac.doc [5. 11. 2019.]

Novalić, Fahrudin (2003), Rasipanje budućnosti - kritika mita napretka i cinizma rasipanja, Zagreb: Alineja.

Organizacija Ujedinjenih naroda za obrazovanje, znanost i kulturu (2006), Smjernice za umjetnički odgoj, Svjetska konferencija o umjetničkom odgoju »Oblikovanje stvaralačkih mogućnosti za 21. stoljeće«, Lisabon: Organizacija Ujedinjenih naroda za obrazovanje, znanost i kulturu.

Palekčić, Marko (2002), »Konstruktivizam - nova paradigma u pedagogiji«, $\mathrm{Na}$ predak, 143(4), str. 403-413.

Palekčić, Marko (2010), »Herbartova teorija odgojne nastave - izvorna pedagogijska paradigma«, Pedagogijska istraživanja, 7(2), str. 319-340.

Palekčić, Marko (2014), »Kompetencije i nastava: obrazovno-politička i pedagogijska teorijska perspektiva«, Pedagogijska istraživanja, 11(1), str. 7-24.

Petrović-Sočo, Biserka (1997), Dijete, odgajatelj i slikovnica, akcijsko istraživanje, Zagreb: Alinea.

Petrović-Sočo, Biserka (2009), Mijenjanje konteksta i odgojne prakse dječjih vrtića: akcijsko istraživanje s elementima etnografskog pristupa, Zagreb: Mali profesor.

Petrović-Sočo, Biserka (2009a), »Značajke suvremenog naspram tradicionalnog kurikuluma ranog odgoja«, Pedagogijska istraživanja, 6(1/2), str. 123-136.

Polić, Milan (2015), »Razložnost odgoja«, Metodički ogledi: časopis za filozofiju odgoja, 22(2), str. 165-188.

Polić, Petra (2015), »Što za pedagogiju znači pitanje o odnosu potreba i prava djeteta?«, Pedagogijska istraživanja, 12(1/2), str. 149-160.

Program odgojno-obrazovnog rada u dječjem vrtiću (1971), Zagreb: Zavod za unapređivanje školstva.

Rajić, Višnja; Petrović-Sočo, Biserka (2015), »Dječji doživljaj igre u predškolskoj i ranoj školskoj dobi«, Školski vjesnik: časopis za pedagogijsku teoriju i prak$s u, 64(4)$, str. 603-620. 
Rakić, Vini; Vukušić, Svjetlana (2010), »Odgoj i obrazovanje za vrijednosti«, Društvena istraživanja: časopis za opća društvena pitanja, 19(4-5), str. 771795.

Sekulić-Majurec, Ana (2007), »Kraj rata paradigmi pedagoških istraživanja«, $P e$ dagogijska istraživanja, 4(2), str. 203-214.

Sindik, Joško (2008), »Poticajno okruženje i osobni prostor djece u dječjem vrtiću«, Metodički obzori: časopis za odgojno-obrazovnu teoriju i praksu, 3(1), str. $143-154$.

Slunjski, Edita (2011), Kurikulum ranog odgoja: istraživanje i konstrukcija, Zagreb: Školska knjiga.

Slunjski, Edita (2011a), »Razvoj autonomije djeteta u procesu odgoja i obrazovanja u vrtiću«, Pedagogijska istraživanja, 8(2), str. 217-228.

Slunjski, Edita (2011b), »Kriteriji kvalitete u situacijama učenja«, Dijete, vrtić, obitelj: časopis za odgoj i naobrazbu predškolske djece namijenjen stručnjacima i roditeljima, 17(64), str. 4-7.

Slunjski, Edita (2011c), »Kako djeca znaju što je znanje vrijedno učenja i kako ga stječu«, Djeca u Europi: zajednička publikacija mreže europskih časopisa, 3(6), str. 18-19.

Slunjski, Edita (2012), Tragovima dječjih stopa, Zagreb: Profil International.

Slunjski, Edita; Burić, Helena (2014), »Akcijsko istraživanje i razvoj nove kulture odnosa temeljene na autonomiji i emancipaciji učitelja«, Školski vjesnik: časopis za pedagogijsku teoriju i praksu, 63(1/2), str. 149-162.

Starc, Branka; Čudina-Obradović, Mira; Pleša, Ana; Profaca, Bruna; Letica, Marija (2004), Osobine i psihološki uvjeti razvoja djeteta predškolske dobi, Zagreb: Golden marketing -Tehnička knjiga.

Vlada Republike Hrvatske (2014), Strategija obrazovanja, znanosti i tehnologije. Dostupno na: http://www.kvalifikacije.hr/sites/default/files/news/2018-01/ Nacrt-prijedloga-strategije-obrazovanja-znanosti-i-tehnologije.pdf $\left[\begin{array}{ll}10 . & 12 .\end{array}\right.$ 2019.]

European Commission (2013), Supporting Teacher Competence Development for Better Learning Outcomes (2013). Dostupno na: https://ec.europa.eu/assets/ eac/education/experts-groups/2011-2013/teacher/teachercomp en.pdf [11. 10. 2019.]

Šagud, Mirjana (2002), Odgojitelj u dječjoj igri, Zagreb: Školske novine.

Šagud, Mirjana (2011), »Inicijalno obrazovanje odgajatelja i profesionalni razvoj«, Pedagogijska istraživanja, 8(2), str. 259-267.

Šimenc, Marjan (2008), »Znanje kao bitni popratni proizvod istraživačke zajednice«, Metodički ogledi: časopis za filozofiju odgoja, 15(1), str. 47-59.

Tischler, Dubravka (2007), »Autonomija učitelja i njihov profesionalni razvoj«, Pedagogijska istraživanja, 4(2), str. 293-298.

Visković, Ivana (2013), »Akcijska istraživanja u funkciji razvoja institucionalnog predškolskog odgoja i obrazovanja«, Educa, 6(6), str. 67-76. 
Vizek Vidović, Vlasta; Vlahović-Štetić, Vesna (2007), »Modeli učenja odraslih i profesionalni razvoj«, Ljetopis socijalnog rada, 14(2), str. 283-310.

Vranješević, Jelena (2005), »Participacija učenika i autoritet nastavnika«, Inovacije u nastavi, 18(4), str. 83-91.

\title{
PICTURE OF A MODERN EDUCATOR IN THE PARADIGM OF EARLY AND PRESCHOOL EDUCATION
}

\author{
Željka Pintar
}

This paper discusses the transformation of a traditional educator in behaviorist educational paradigm, which was characteristic to a socialist period in the Republic of Croatia, into a modern one, who is an advocate of a constructivist educational concept, characteristic to the period of democratic life. The paper addresses key differences and similarities between traditional and modern educators in order to better understand expectations and criteria for successful performance in the contemporary educational activity. Implicit pedagogy is also discussed as an educator's subjective educational theory. The justification of its understanding as a key construct of the educational concept is pointed out. The paper also emphasizes the importance of reflective practice as a component of educator's professional development, and problematizes implementation of action research as an instrument for development of educator' s activity.

Key words: contemporary educator, implicit pedagogy, action research 